\section{EREM 74/3}

Journal of Environmental Research, Engineering and Management

Vol. 74 / No. 3 / 2018

pp. $64-73$

DOI 10.5755/j01.erem.74.3.21100

(c) Kaunas University of Technology
Development of Diagnostic Test Systems Using Nanoparticles for Determination of Markers of Ecologically Significant Diseases

\begin{tabular}{|l|r|}
\hline Received 2018/05 & Accepted after revision 2018/10 \\
\hline Cross & http://dx.doi.org/10.5755/j01.erem.74.3.21100 \\
\hline
\end{tabular}

\title{
Development of Diagnostic Test Systems Using Nanoparticles for Determination of Markers of Ecologically Significant Diseases
}

\section{Stoinova Anastasia}

Peoples' Friendship University of Russia (RUDN University), 117198, Moscow Miklukho-Maklaya str. 6

\section{Zubkov Alexander}

Mechnikov Research Institute of Vaccines and Sera

\section{Panchenko Valentina, Stanishevskiy Yaroslav}

Vinnytsia National Agrarian University, Soniachna 3, Vinnytsia, 21008, Ukraine

\section{Corresponding author: stoinova17@mail.ru}

Stoinova A., Peoples' Friendship University of Russia (RUDN University)

Diseases of animals and humans are largely environmentally related. With the timely detection of the disease, it is possible to avoid severe consequences, both for human health, animals, and the environment as a whole. The article describes the process of creating diagnostic test systems, including obtaining used nanoparticles and describing their physicochemical properties as the kinetics of gold and silver nanoparticles in mono- and binary hydrosols using spectroscopic methods of investigation, determined the size of silver nanoparticles on the basis of the method of cross-correlation spectroscopy of photons and transmission electron microscopy and the effect of ultrasound on the spectroscopic data hydrosols of gold and silver. The article contains a description of the technology of obtaining bionanoconjugates - a key link for creating diagnostic test systems. The results of the development of diagnosticums are presented at the end of the article and the corresponding conclusions are drawn.

Keywords: ecologically significant diseases, diagnostic test system, silver nanoparticles, gold nanoparticles, kinetics, sonication, bionanoconjugates. 


\section{Introduction}

As it turns out, diseases are largely environmentally conditioned. As much as $60 \%$ of human infectious diseases are zoonotic, that is, they originate from animals. More than two-thirds of them originate in the wild (Cavaletti, 2018). Several teams of veterinarians and environmental specialists, together with medical scientists and epidemiologists, are making efforts at the global level in order to understand the ecology of the disease. Their work is part of a project called "Predict", which is funded by the United States Agency for International Development (USA AID, 2013). This enables global surveillance for pathogens that can spillover from animal hosts to people by building capacities to detect and discover viruses of pandemic potential. The project is part of USAID's Emerging Pandemic Threats programme and is led by the UC Davis One Health Institute. The core partners are USAID, EcoHealth Alliance, Metabiota, Wildlife Conservation Society, and Smithsonian Institution. Experts are trying to understand how, based on the knowledge of manmade changes in the landscape, for example, the construction of a new farm or a road, it is possible to predict where new diseases for mankind will penetrate us, and how to detect them on time, that is, before they manage to spread. Researchers take samples of blood, saliva and other biomaterials from animals of the species that bear the greatest threat of spreading the infection, in order to create a unique catalogue of viruses, which would allow one to quickly identify the virus in case of infection of a person. The question of disease diagnostics is very important in contemporary medicine. The necessary preventive measures and drug therapy in the incipient stages of the disease can be very effective in fighting for the life and health of a patient. The rudimentary stages of developing diagnostic test systems for determining the presence of viral antigens in the blood of patients are depicted in this research work. The presented development is supplemented by actual nanotechnologies for obtaining bionanoconjugates of gold nanoparticles with antibodies to antigen.

Among the most widely used nanoparticles in various fields of human activities are gold and silver nanoparticles (AuNPs and AgNPs). That is why their production requires a very detailed examination. The mode of preparation, the shape and specific properties of gold and silver NPs, the application of AuNPs in analytical biosensing and bioimaging and AgNPs as antibacterial components are the subject of intensive studies (Lisichkin, 2001; Khlebtsov et al., 2013; Rand et al., 2011; Zhu et al., 2016). In biology, quantum dots of silver sulphide are used as fluorescent labels (Rand et al., 2011). Gold nanoparticles as colour markers are used for the early diagnosis of carcinomas (Zhu et al., 2016). The well-known antibacterial properties of nanosilver are used in medicine and pharmacy, e.g., for the production of antimicrobial dressings in surgery and as one of the possible methods of cancer treatment (Stanishevskaya et al., 2016).

A new field of nanobiotechnology is called theranostics (Bhujwalla, 2018). The summary of biomedical applications of AuNPs and AuNP-based multifunctional nanocomposites was given in a review (Khlebtsov et al., 2013). Different geometrical forms of plasmonic AuNPs such as 16 nanometers (nm) Au nanospheres, Au nanorods, AuAg nanorods, SiO2/Au nanoshells, Au nanostars, Ag nanocubes, AuAg nanocages, etc. visualized by transmission electron microscopy (TEM) image may be also easily detected using absorption spectra. If AuNPs are aggregating absorption spectra become broadened and red-shifted (Stanishevskaya et al., 2016). The aggregation of AuNPs and AgNPs in colloids with tannin stabilisation caused by low-temperature treatments $(77 \mathrm{~K})$ was studied previously (Khlebtsov, 2008; Kononova, 2010). It is necessary to mention that different changes in plasmon spectra for gold and silver NPs were obtained.

This article describes the results of kinetics of NPs formation in tannin stabilised $\mathrm{Au}$ and $\mathrm{Ag}$ hydrosols, the shape and size characteristics of NPs and the influence of ultrasound treatments on the size and plasmonic spectra of mono- and binary AuAg hydrosols. The purpose is to obtain silver and gold nanoparticles with a narrow particle size distribution and to check the effect of ultrasonic treatment on its properties. The study of the properties of nanoparticles is necessary for the construction of bionanoconjugates used in diagnostic test systems. In the modelling of various 
diagnostic systems, the used conjugates consist of a polymer particle that contains on its surface specific bio-ligands capable of affinity binding to a detectable component (antigen, antibody). For example, antibodies against the bird Newcastle Disease Virus were taken as a bioligand. The immune activity of this biomolecule depends on how the polymer will attach an antibody to itself and whether the active site of the protein will be blocked. Therefore, it was proposed to immobilise gold nanoparticles on the antibody surface in various concentrations to select the optimal conditions for conjugate creation. It is expected that, due to their small size, they will not block the antibody active centres (Stoinova et al., 2018).

\section{Methods}

To prepare Ag nanoparticles in sol by the reducing method, we used silver nitrate (I), silver sulphate (II) and tetrachloroaurate acid as precursors, added in tannin (Germany) in tetra borate buffer solution. This biopolymer is a good stabiliser and a smooth reducing substance. The metal concentration in sols was $0.001 \%$ wt.

According to reactions, silver and gold ions form nanoparticles and tannin $\mathrm{C}_{76} \mathrm{H}_{52} \mathrm{O}_{46}$ transforms into flobaphen $\mathrm{C}_{76} \mathrm{H}_{52} \mathrm{O}_{49}$ :

$6 \mathrm{Ag}++\mathrm{C}_{76} \mathrm{H}_{52} \mathrm{O}_{46}+6 \mathrm{OH}-\rightarrow 6 \mathrm{Ag}+\mathrm{C}_{76} \mathrm{H}_{52} \mathrm{O}_{49}+3 \mathrm{H}_{2} \mathrm{O}$
$\mathrm{AuCl}_{4}-+\mathrm{C}_{76} \mathrm{H}_{52} \mathrm{O}_{46}+6 \mathrm{OH}-\rightarrow \mathrm{Au}+\mathrm{C}_{76} \mathrm{H}_{52} \mathrm{O}_{49}+3 \mathrm{H}_{2} \mathrm{O}$

Tannin presents in solution in excess; thus, the ionic form of silver and gold is impossible in resulting sols, which was confirmed by means of special tests. Au and $\mathrm{Ag}$ hydrosols in tannin are very stable and their optical characteristics do not change in 2 or more years.

For characterisation of silver and gold NPs, we used absorption spectra (PerkinElmer Lambda 650/850/950 UV/VIS Spectrometer) and TEM images (transmission electron microscope JEOL JEM-2100). The size distributions of silver and gold nanoparticles were obtained by the method of cross-correlation of photons (Nanophox Sympatec $\mathrm{GmbH}$ ). The surface charge of nanoparticles was determined by the method of electrophoretic light scattering. This method is based on a physical phenomenon such as electrophoresis:

a sample of gold and silver sols was placed in a cuvette provided with two electrodes;

an electric field was applied, which led to the movement of the nanoparticles to the oppositely charged electrode at a rate associated with the zeta potential.

This experiment was carried out using a particle size and zeta potential analyser based on the laser light scattering technology of Malvern. The particle motion due to the applied electric field is measured by light scattering. The particles are illuminated by laser light and, therefore, they scatter light. The frequency of the scattered light depends on the velocity of the particle due to the Doppler shift. This explains another name for this technique: laser Doppler electrophoresis. The second ray of light (reference beam) is mixed with the scattered beam to accurately extract the frequency shift into the scattered light.

Antibody conjugates with nanoparticles were prepared by the following method:

antibodies to the Newcastle virus were mixed in an amount of $1 \mathrm{~mL}$ with $1 \mathrm{~mL}$ of sol, a concentration of 2, 4, 8, 16, 32, $64 \mathrm{mg} / \mathrm{mL}$;

the tubes with the samples on the orbital shaker were then incubated at $200-250 \mathrm{rpm},+37^{\circ} \mathrm{C}, 12$ hours.

The formation of bionanoconjugates was monitored by transmission electron microscopy (TEM JEOL JEM-2100).

\section{Results and Discussion}

The kinetics of nanoparticle formation were analysed by monitoring the absorption spectra (Fig. 1). Measurements were carried out starting from the fifth minute after mixing all the components of the sol.

The resulting curves (Fig. 2) show how the optical density in absorption maximum increases in time of the reducing reaction. For silver (II) and gold sol formation finish after 10 and 5 minutes, respectively; however, for silver (I), the process is not so quick. 
Fig. 1

Optical absorption spectra during formation of silver I (a) and gold (b) hydrosols
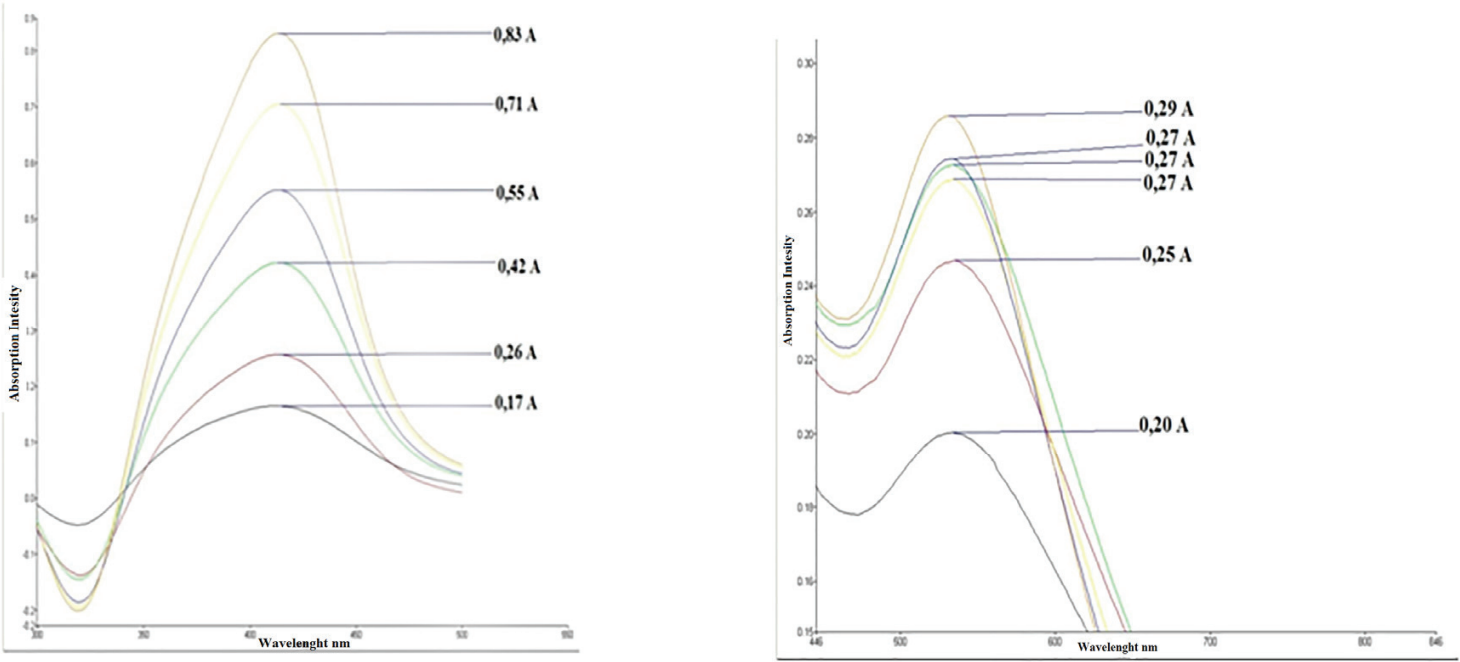

a

b

Fig. 2

Time dependences of NPs absorption in spectra maximum for silver (a) and gold (b) hydrosol formation

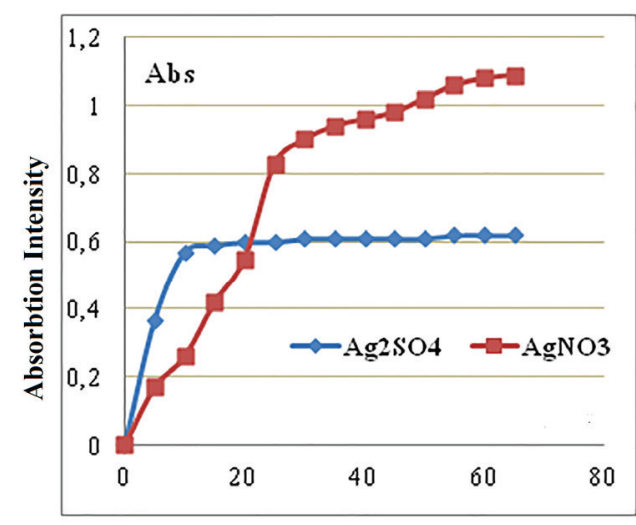

Duration of sols formation, minutes

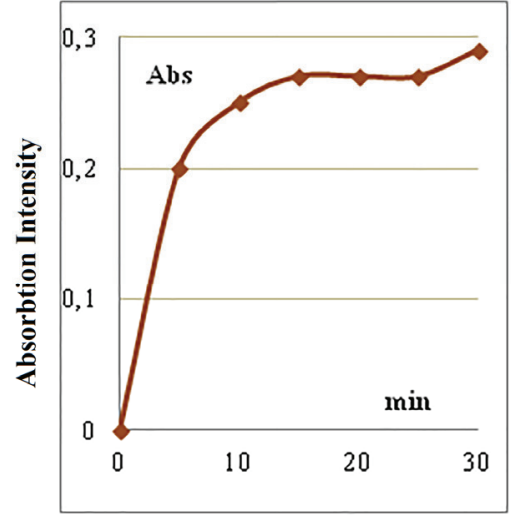

Duration of sols formation, minutes
For silver nanoparticles in hydrosols, the absorption maximum $\left(A_{\text {max }}\right)$ near $400 \mathrm{~nm}$ is typical and corresponds plasmon spectra. The spectra maximums do not shift during the reaction. However, the asymmetric spectra form (Fig. 1a) indicates the additional absorbance below $400 \mathrm{~nm}$ that corresponds to $\mathrm{Ag}$ clusters. Spectra of AuNPs are symmetric, and $A_{\max }$ is near $530 \mathrm{~nm}$.

The dependences of $A_{\max }$ with duration of sol formation from $\mathrm{AgNO} 3$ and $\mathrm{Ag} 2 \mathrm{SO} 4$ precursors are different (Fig. 2a). The reaction is over in 10 minutes if sulphate salt is used. 
The silver reducing process has two stages - quick (1) and slow (2), as well as Au sol formation. The gradients characterise the rate of NPs appearance and the values are given in Table 1. The initial rate for Ag NPs in case of $\mathrm{Ag} 2 \mathrm{SO} 4$ is 2 times bigger in comparison with AgNO3 and similar to the rate value for gold.

Then the resulting nanoparticle sizes were obtained by the method of cross-correlation of photons (Fig. 3).
Table 1

The rates of NPs formation (min.-1) for 2 stages and 2 AgNPs precursors

\begin{tabular}{c|c|c|c|c|c}
\hline \multicolumn{3}{c|}{ Silver } & \multicolumn{2}{c}{ Gold } \\
\hline \multicolumn{2}{c|}{ AgNO3 (I) } & \multicolumn{2}{c|}{ Ag2SO4 (II) } & \multicolumn{2}{c}{ HAuCl4 } \\
\hline 1 & 2 & 1 & 2 & 1 & 2 \\
\hline 0.031 & 0.006 & 0.057 & 0 & 0.025 & 0.0016 \\
\hline 0.974 & 0.968 & 0.971 & & 0.893 & 0.8 \\
\hline
\end{tabular}

\section{Fig. 3}

The size distribution of $\mathrm{Ag}$ and $\mathrm{Au}$ sol nanoparticles in diameter
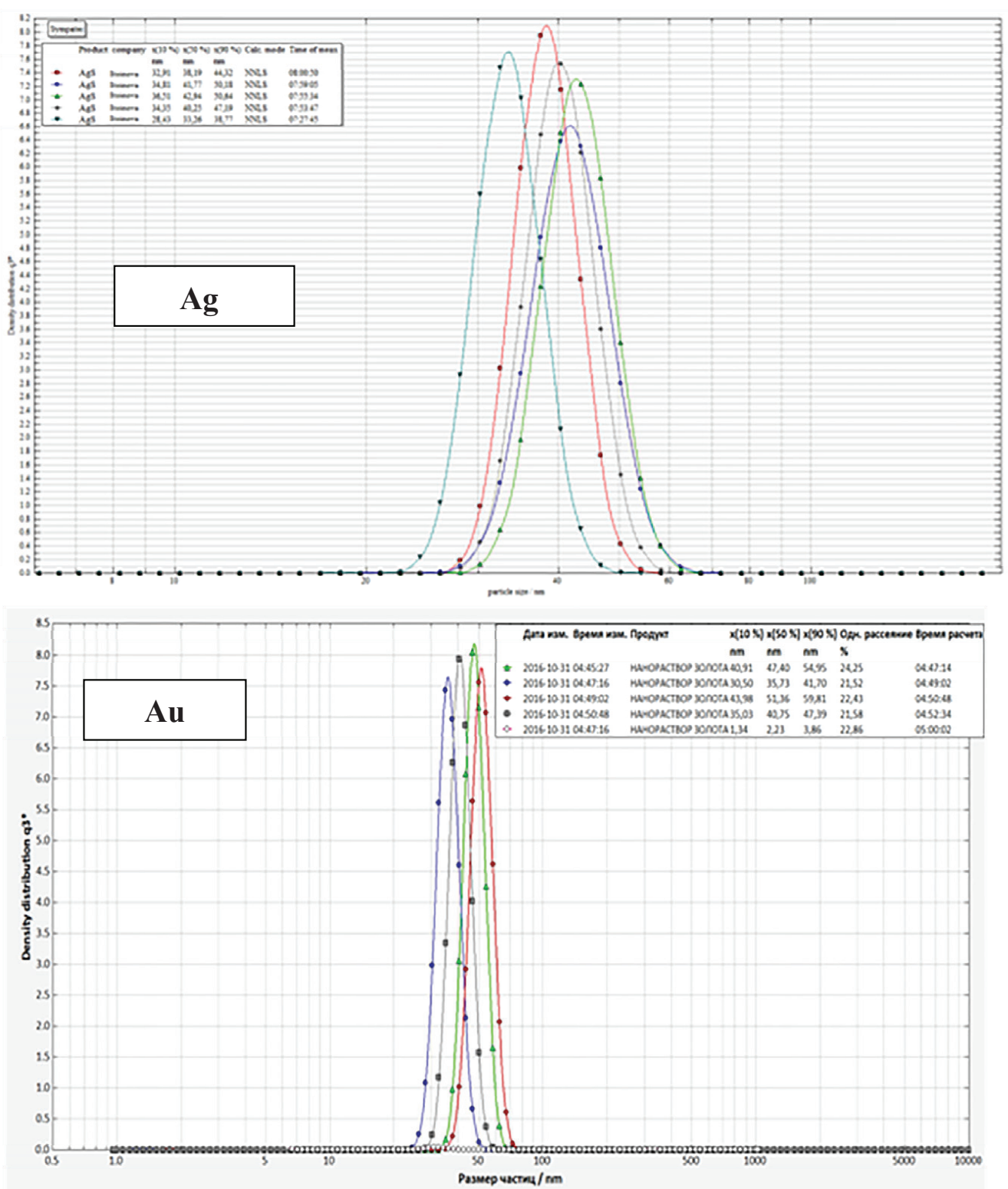
The curves on the graph show that the obtained silver and gold nanoparticles have a narrow size distribution and the diameter is in the range from 30 to $50 \mathrm{~nm}$; the maximum number of particles fall on the size of about $40(\mathrm{Ag})$ and $44(\mathrm{Au}) \mathrm{nm}$.

The gold nanoparticles also obtained a narrow size distribution in the range from 30 to $70 \mathrm{~nm}$, and the maximum number of particles fall on the size of about $50 \mathrm{~nm}$ (Table 2).

\section{Table 2}

Diameters (D) of metallic nanoparticles in silver and gold hydrosols and size intervals $\Delta=$ Dmax-Dmin

\begin{tabular}{l|c|c|c|c}
\hline & \multicolumn{2}{|c|}{ Ag NPs (precursor ////) } & \multicolumn{2}{c}{ Au NPs } \\
\hline \multicolumn{1}{|c|}{2} & 2 & 3 & 4 & 5 \\
\hline № & $\mathrm{HB}, \mathrm{nm}$ & $\Delta \mathrm{nm}$ & $\mathrm{HB}$ & $\Delta \mathrm{nm}$ \\
\hline 1 & 38.19 & 6.13 & 47.40 & 14.04 \\
\hline 2 & 41.77 & 8.41 & 35.73 & 11.20 \\
\hline 3 & 42.94 & 7.7 & 51.36 & 15.83 \\
\hline 4 & 40.25 & 6.67 & 40.75 & 12.36 \\
\hline 5 & 33.26 & 5.51 & & \\
\hline average & 39.28 & 6.88 & 43.81 & 13.36 \\
\hline
\end{tabular}

The TEM results confirm that the size of gold and silver nanoparticles is about 40 nanometers (Fig. 4).

Based on the results of the research, the obtained nanoparticles are irregular formations. The bands on the surface of the particle indicate that the spatial structure of silver and gold nanoparticles is stepped, i.e., the structure of particle formation in time is visible.

Bimetallic Ag-Au hydrosols. To create bimetallic nanocomposites, we mixed available hydrosols of silver and gold in various concentrations. Then, we fixed the kinetics of formation of bimetallic particles obtained sols (Fig. 5).

The more gold nanoparticles there are in the obtained sol, the more gold characteristic maximum absorption spectrum is shown in the graph, and vice versa. A gradual displacement of the plasmon resonance band from $400 \mathrm{~nm}$, characteristic of pure silver, to $550 \mathrm{~nm}$, characteristic of gold, clearly illustrates the change in the composition of bimetallic sols. Finally, stable
Fig. 4

TEM image of gold and silver nanoparticles in tannin stabilised hydrosol
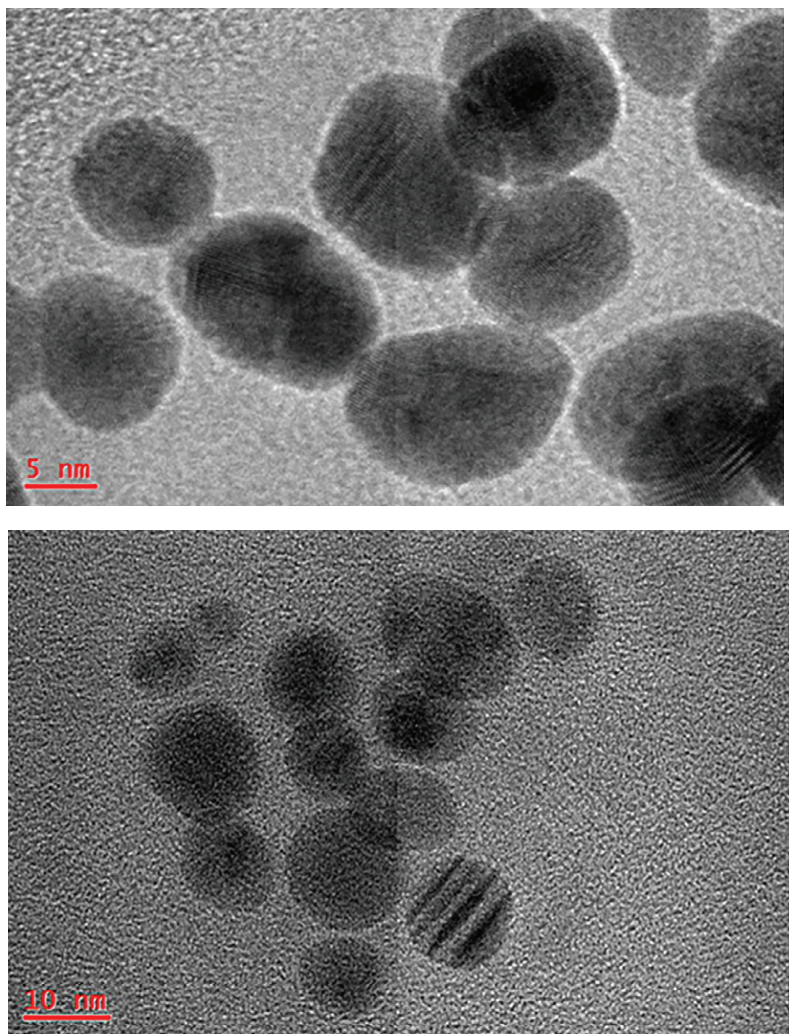

Fig. 5

The kinetics of binary gold and silver hydrosol stabilisation

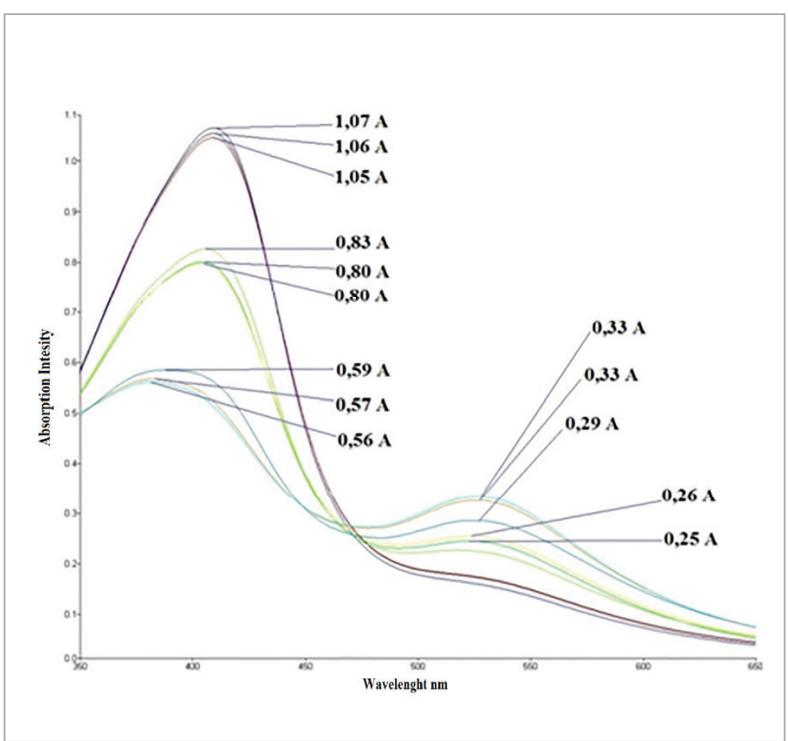


hydrosols were sonicated during $10 \mathrm{~min}$ at a constant frequency of $25.56 \mathrm{~Hz}$, by varying the power of exposure at 10, 20, and 30\%. After ultrasonic treatment, absorption spectra sols were recorded (Fig. 6).

\section{Fig. 6}

The changes in PL spectra under ultrasonic processing of $\mathrm{Ag}$ and $\mathrm{Au}$ hydrosols

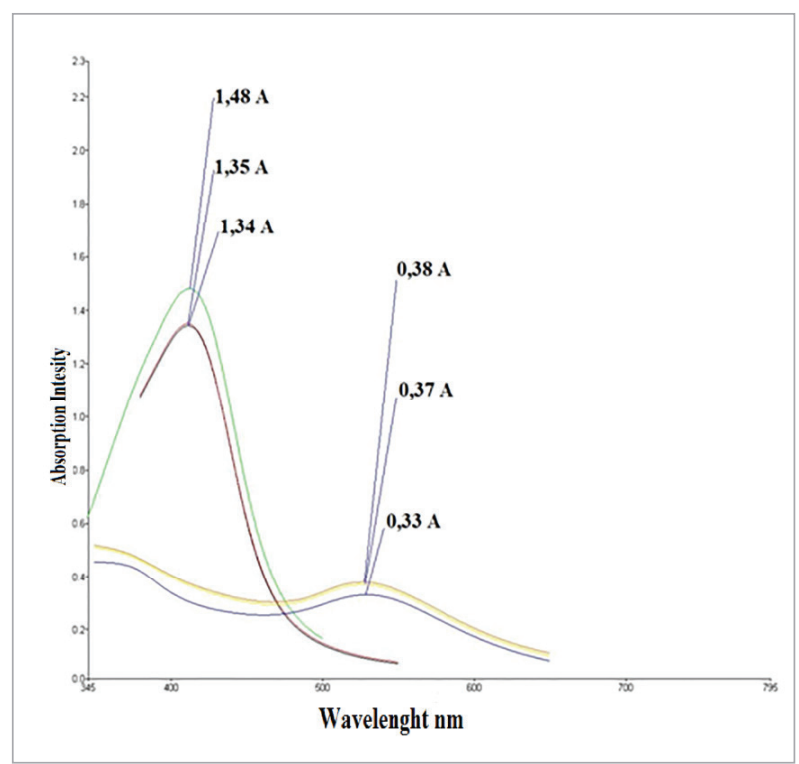

Surface-bound charge is usually quantitatively determined by the zeta potential (ZP), a parameter that gives information on the net charge of particles in a liquid medium. Its value is closely related to the stability of the suspension and the surface coating of the particles. Therefore, it is commonly used to determine particle stability and surface adsorption. Surface charge affects the interactions between particles and biological molecules, and the stability of complexes during the interaction of nanoparticles with proteins. Therefore, surface charge of nanoparticles is a critical parameter for determining both the stability and the functionality of the complexes formed. It has also been proven that positively charged gold nanoparticles can penetrate the cell membrane, and negatively charged gold nanoparticles do not pass through the membrane, but under certain conditions can prevent its destruction. Au (ZP) -14.7, Ag (ZP) -12.9.

Conjugation of various fragments with nanoparticles expands the field of their application and gives them
Fig. 7

Distribution of the zeta potential of the samples with silver and gold nanoparticles

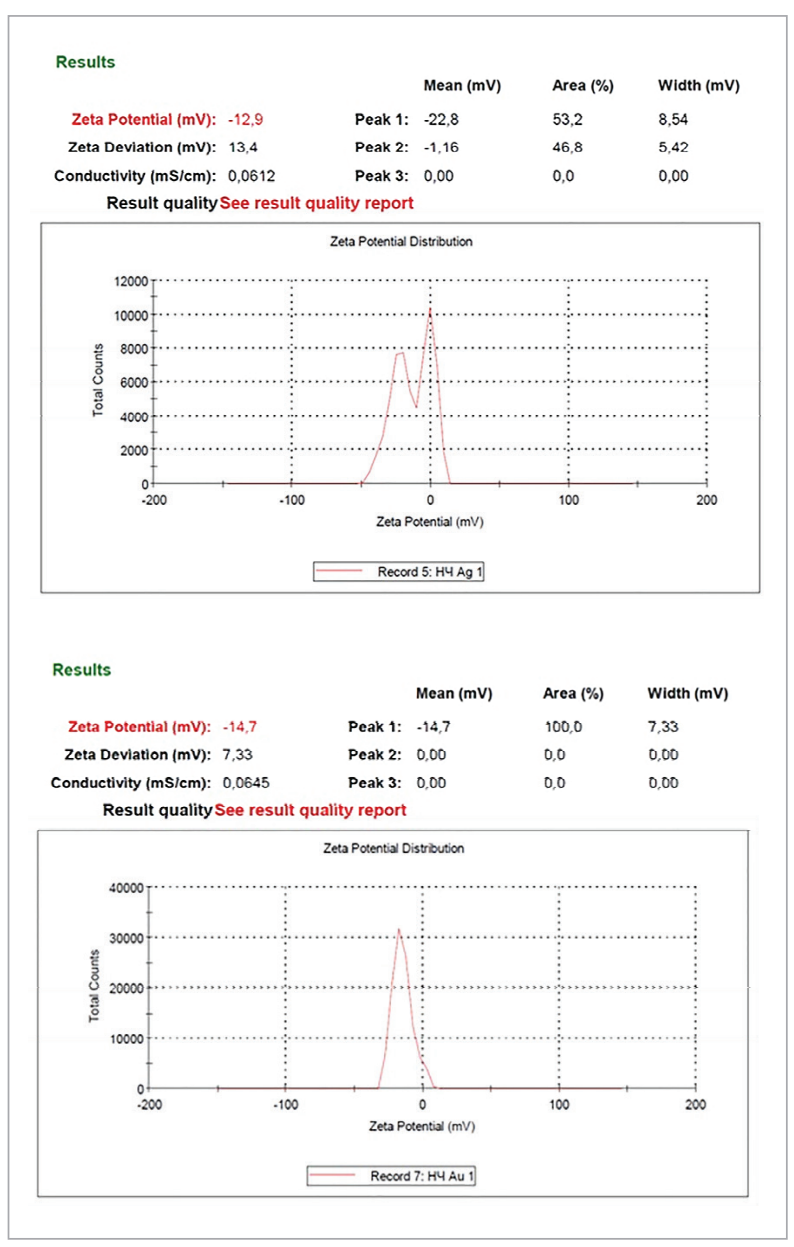

new improved properties. The conjugation of nanoparticles with antibodies combines the properties of the nanoparticles themselves with the ability of antibodies to specifically recognise antigens. In addition, improved cellular uptake, as well as basic intracellular stability, can be the two main advantages of using nanoparticulate conjugated antibodies. Antibody-conjugated nanoparticles can be used mainly in two biomedical directions: therapy and diagnostics. Autoantibody conjugates with gold and silver nanoparticles were obtained, respectively. The physical interaction between antibodies and nanoparticles depends on three phenomena: ionic attraction between negatively charged gold/silver and a positively charged antibody; hydrophobic attraction between the antibody and the 
gold surface; and binding between the gold-conducting electrons and the amino acid sulphur atoms of the antibody. For the conjugation of antibodies with nanoparticles, non-covalent immobilisation regimes were used. The antibodies were adsorbed on gold and silver nanoparticles non-specifically, while maintaining a negative particle charge and providing stability in the colloidal solution. In other words, non-covalent binding methods are used in the bioconjugation protocol based on a combination of electrostatic and hydrophobic interactions of the antibody with the surface of gold and silver. There are several types of interactions that can occur in this process: hydrophobic interactions, ionic interactions, etc. Hydrophobic interactions are associated with the attraction between the hydrophobic parts of the antibody and the surface of the metal, which lead to the formation of a non-covalent bond. The antibodies contain positively charged groups (amino acids) at the N-terminus. Ion interactions are formed between these groups and the negatively charged surface of nanoparticles. These conjugates were studied using a transmitting electron microscope. The photograph shows the formation of conjugates by immobilising the nanoparticle onto the surface of the protein.

As seen in this picture, the formation of bionanoconjugates proceeds with a low yield. Covalent binding of silver and gold nanoparticles to the surface of the protein is clearly expressed in the photograph from the microscope. However, it is also possible to observe that nanoparticles are located outside the hydrate shell of the protein molecule. This circumstance can be explained by the fact that affinity binding centres in proteins, by the time of their investigation on a microscope, already attracted a sufficient number of nanoparticles; therefore, the rest remained floating in the test solution. Such conjugates can be used to construct diagnostic test systems, for the detection of environmentally caused diseases of animals and humans. With the help of such complexes, diagnostic strips can be created, which will be a cut of nitrocellulose paper, on which the control line and the test line will be applied. By omitting this strip in the test solution, it will be possible to detect the presence of certain antibodies to the antigen-virus.

Fig. 8

TEM data of bionanoconjugates

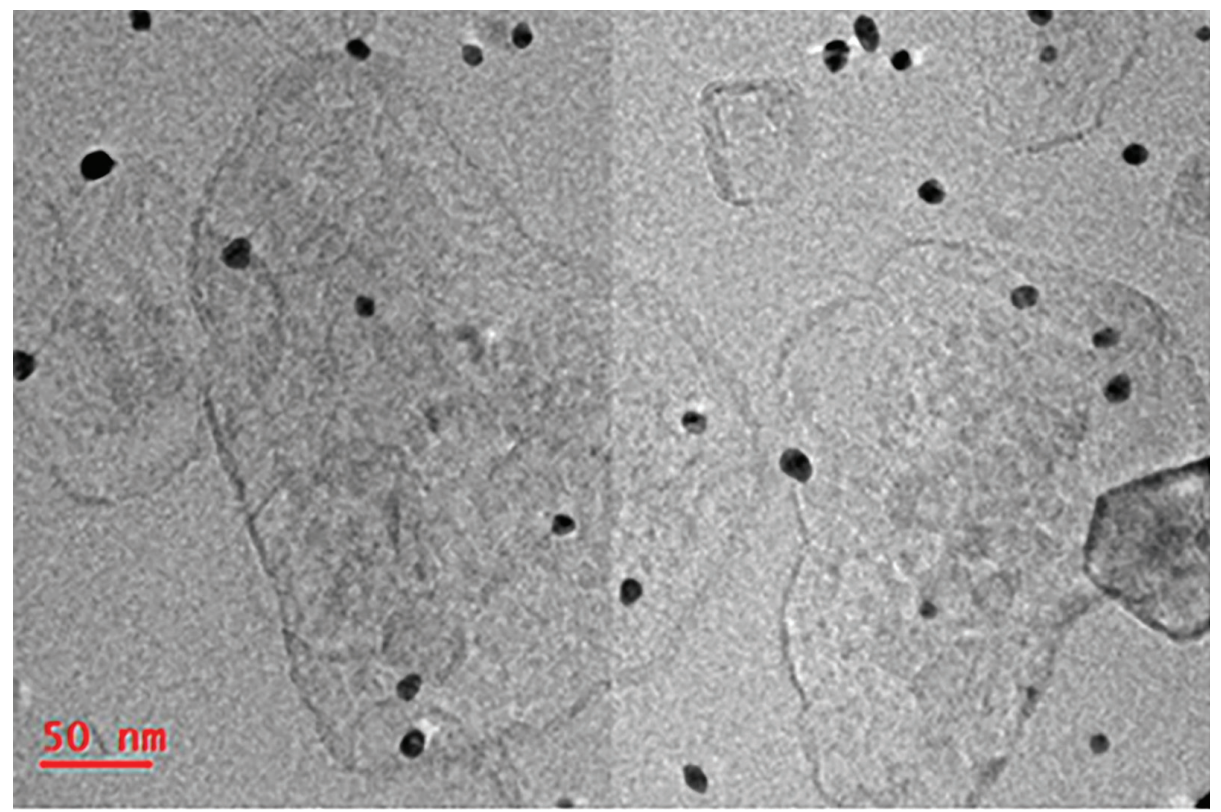




\section{Conclusions}

1 Silver and gold nanoparticles were synthesised by the method of chemical reduction of tannin.

2 The formation of nanoparticles did not pass linearly; however, the study of this process led to the conclusion that, when adding more buffer solution, the process of nanoparticle formation was slower.

3 Physical characteristics of nanoparticles were studied and it was shown that the size of gold and silver nanoparticles is $40 \mathrm{~nm}$; the surface charge of gold nanoparticles is -14.7 , and the surface charge of silver nanoparticles is 12.9 .

\section{References}

Bhujwalla Z.(2018) Journal of Magnetic Resonance. Theranostics and metabolotheranostics for precision medicine in oncology (291): 141-151

Cavaletti A. (2018) Value in Health Regional Issues. Social Context and Geographic Space: An Ecological Study about Hospitalizations of Older Persons (17): 8-13.

Khlebtsov N.(2008) Quantum Electron. Optics and biophotonics of nanoparticles with a plasmon resonance(38): 504-529.

Kononova E., Mikhalenko I. (2010) Russian Journal of Physical Chemistry A. Effect of low-temperature treatment on the state of gold hydrosol particles. № 6: 1053-1058.

Khlebtsov N.(2013) Theranostics. Analytical and Theranostic Applications of Gold Nanoparticles and Multifunctional Nanocomposites 3(3): 167-180.

Lisichkin G.(2011) Chemlnform. Metal Nanoparticles in Condensed Media: Preparation and the Bulk and Surface Structural Dynamics. 42-52
4 Immobilisation of autoantibodies to thyroglobulin with silver and gold nanoparticles was carried out.

5 The obtained bionanoconjugates were examined by TEM, which showed that the conjugates were formed by affinity attachment with covalent bonds. These conjugates are stable and can be used to design diagnostic test systems that will solve problems of environmentally caused diseases.

\section{Acknowledgements}

The publication was prepared with the support of the "RUDN University Program 5-100".

Rand D., Ortiz V. (2011) Nano Letters. Nanomaterials for X-ray imaging: Gold nanoparticle enhancement of X-ray scatter imaging of hepatocellular carcinoma. 2678-2683.

Stanishevskaya I., Stoynova A.(2016) Development and registration of medicinal products. Silver nanoparticles: preparation and use for medical purposes. №1 (14): 66-69.

Stoinova A., Stanishevskiy Ya. (2018) FEBS Bio. Engineering research of bionanoconjugates for diagnostic test systems of autoimmune diseases.

USA AID (2013) Project Predict. Emerging Pandemic Threats (EPT) program.

Zhu B., Li Y., Lin Z.(2016) Nanoscale Research Letters, Silver Nanoparticles Induce HePG-2 Cells Apoptosis Through ROS-Mediated Signaling Pathways (11): 198 -206. 


\section{Diagnostikos testavimo sistemų, naudojančių nanodaleles, nustatymas ekologiškai reikšmingų ligų žymeklių nustatymui}

\section{Stoinova Anastasija}

Rusijos tautų draugystės universitetas (RUDN universitetas), Maskva, Rusija

\section{Zubkov Aleksandras}

Mechanikos tyrimų institutas, Maskva

\section{Panchenko Valentina, Stanishevskiy Yaroslav}

Rusijos tauty draugystés universitetas (RUDN universitetas), Maskva, Rusija

Gyvūnų ir žmonių ligos daugiausia susijusios su aplinka. Laiku aptikus ligą, galima išvengti didelių padarinių žmonių sveikatai, gyvūnams ir visai aplinkai. Straipsnyje aprašoma sukurti diagnostikos tyrimo sistemos, iskaitant gauti, kurios naudojamos nanodaleles ir aprašant ju fizikines ir chemines savybes kaip aukso ir sidabro nanodalelių mono- ir dvieju komponentu hydrosols naudojant spektroskopowych tyrimo metodus kinetiką procesą, nustatė sidabro nanodalelių dydžio remiantis fotonų kryžminès koreliacijos spektroskopijos metodas ir transmisinès elektroninès mikroskopijos metodas bei ultragarso poveikis spektroskopinių duomenų hidrozolams iš aukso ir sidabro. Straipsnyje pateikiamas bionanokonjugatu gavimo technologijos aprašymas - pagrindinè diagrama bandymu sistemu sukūrimo link. Straipsnio pabaigoje pateikiami diagnostinių priemoniu kūrimo rezultatai ir pateikiamos atitinkamos išvados.

Raktiniai žodžiai: ekologiškai reikšmingos ligos, diagnostinè testų sistema, sidabro nanodalelès, aukso nanodalelès, kinetika, ultragarso technika. 